\title{
Purification and Characterization of a Third Glucosyltransferase from Streptococcus mutans Serotype $g$
}

\author{
By NOBUHIRO HANADA, TADAMICHI TAKEHARA* AND \\ EIICHI SAEKI \\ Department of Preventive Dentistry, Kyushu Dental College, Kokurakita-ku, Kitakyushu 803, \\ Japan
}

(Received 7 April 1986; revised 9 September 1986)

Streptococcus mutans strain AHT (serotype $g$ ) secretes at least two glucosyltransferases with different $\mathrm{pI}$ values. A novel glucosyltransferase with a pI of 5.8 was purified 244 -fold from the ammonium sulphate fraction by DEAE-cellulose chromatography, FPLC (Mono Q column, Pharmacia) and hydrophobic chromatography. The enzyme preparation gave a single protein band on analysis by both PAGE and SDS-PAGE, and did not form multiple protein bands detectable by IEF. The $M_{\mathrm{r}}$ was estimated to be about 130000 by SDS-PAGE and about 135000 by ultracentrifugal analysis. The apparent $K_{\mathrm{m}}$ value and $\mathrm{pH}$ optimum of the enzyme were $3.9 \pm 0.2 \mathrm{~mm}$ (mean $\pm \mathrm{SD}$ ) and about 4.7 , respectively. The enzyme synthesized water-soluble glucan from sucrose, and the glucan consisted of over $90 \mathrm{~mol} \% 1,6-\alpha$-D-glucosidic linkages. The enzyme activity was not stimulated by primer dextran. Anti-enzyme serum produced a single precipitin band with the purified enzyme preparation, whereas it did not react with either of the other two known glucosyltransferases.

\section{INTRODUCTION}

It has been suggested by several authors that various strains of Streptococcus mutans secrete at least two glucosyltransferases synthesizing different products (Ciardi et al., 1977; Fukushima et al., 1981; Robyt \& Martin, 1983; Koga et al., 1983). One of these glucosyltransferases synthesizes a water-insoluble glucan, and the other, a water-soluble glucan. Shimamura et al. (1983) reported that there is a third glucosyltransferase existing in multiple form (pI 5.5-7.0) in $S$. mutans 6715 (serotype $g$ ) which is different from previously purified glucosyltransferase (Shimamura et al., 1982). However, this enzyme has not yet been purified and characterized. We have also found a fourth glucosyltransferase isolated from $S$. mutans AHT (serotype $g$ ) (Takehara et al., 1984), the characterization of which will be described elsewhere (N. Hanada \& T. Takehara, unpublished).

In this report, we describe the purification and characterization of the third glucosyltransferase from $S$. mutans AHT.

\section{METHODS}

Materials. S. mutans AHT (serotype $g$, subculture AHT-k; Hamada et al., 1978) was kindly provided by Dr M. Inoue, Kagoshima University Dental School, Kagoshima, Japan. An electrophoresis calibration kit (HMW), an IEF calibration kit, Pharmalyte, Octyl-Sepharose CL-4B, Dextran T10 (DT 10) and Dextran T2000 (DT 2000) were purchased from Pharmacia, alcohol dehydrogenase (EC 1.1.1.1; from yeast) from Sigma, catalase (EC 1.11.1.6; bovine) from Boehringer Mannheim, DEAE-cellulose (DE 52) from Whatman, Bio-Gel A-5m from Bio-Rad, Ultrogel AcA 34 from LKB, Freund's incomplete adjuvant from Difco, and Schiff reagent from Merck. All other chemicals were of analytical grade.

Abbreviations: FPLC, fast protein liquid chromatography; IEF, isoelectric focusing; PAS, periodic acid-Schiff. 
Culture conditions. S. mutans AHT was grown anaerobically for $18 \mathrm{~h}$ at $37^{\circ} \mathrm{C}$ in Trypticase, tryptose and yeast extract/glucose broth (Hamada \& Torii, 1978). Screw-capped laboratory bottles were used to obtain twenty 5 -litre batches $(1001)$.

Enzyme assay. Total glucosyltransferase activity was determined by measuring the amount of glucan synthesized in the presence of sucrose. An enzyme sample $(0.9 \mathrm{ml})$, containing $0.1 \mathrm{M}$-sodium acetate buffer, $\mathrm{pH} 6 \cdot 0,5 \%(\mathrm{w} / \mathrm{v})$ sucrose and $5 \mathrm{~mm}$-sodium fluoride, was incubated at $37^{\circ} \mathrm{C}$ for $18 \mathrm{~h}$, and the total polysaccharides subsequently precipitated with $70 \%(\mathrm{v} / \mathrm{v})$ ethanol and harvested by centrifugation $(1500 \mathrm{~g}, 30 \mathrm{~min})$. Glucan was quantified by a modification of the anthrone method (Halhoul \& Kleinberg, 1972). For determination of enzyme kinetics, the incubation time was $60 \mathrm{~min}$ in the same reaction mixture, except that the buffer $\mathrm{pH}$ was 4.7 . One unit (U) of glucosyltransferase activity was defined as the amount of enzyme catalysing the incorporation of $1 \mu \mathrm{mol}$ glucose from sucrose into glucan per $\min$ in the reaction mixture described above.

The priming effect of glucan synthesized by glucosyltransferase was studied by measuring the activity in the

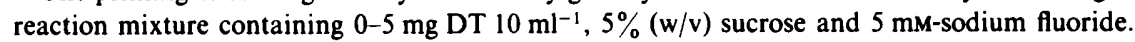

Water-insoluble glucan synthetic activity was determined by measuring the amount of water-insoluble glucan synthesized in the presence of $5 \%(\mathrm{w} / \mathrm{v})$ sucrose, DT $10\left(5 \mathrm{mg} \mathrm{ml}^{-1}\right)$ and $5 \mathrm{mM}$-sodium fluoride.

Dextranase activity was assayed in the reaction mixture with DT $2000\left(0.5 \mathrm{mg} \mathrm{ml}^{-1}\right)$ in $0.4 \mathrm{ml} 50 \mathrm{mM}$-sodium acetate buffer, $\mathrm{pH} 6.0$. Before and after incubation at $37^{\circ} \mathrm{C}$ for $18 \mathrm{~h}$, the amount of reducing sugar released was measured by the method of Park \& Johnson (1949), using glucose as a standard, and the net increase of reducing sugar was calculated.

Purification. All procedures were carried out at $0-4{ }^{\circ} \mathrm{C}$ except for FPLC and HPLC. One hundred litres of culture liquor was centrifuged at $7000 \mathrm{~g}$ for $20 \mathrm{~min}$ and the cell-free culture supernatant was precipitated with ammonium sulphate at $50 \%$ saturation. The precipitate was then collected by centrifugation $(11000 \mathrm{~g}, 60 \mathrm{~min})$, suspended in $20 \mathrm{~mm}$-Tris $/ \mathrm{HCl}$ buffer, $\mathrm{pH} 7.5$, and dialysed against the same buffer.

The crude enzyme $(540 \mathrm{ml})$ was applied to a DEAE-cellulose column $(9 \times 36 \mathrm{~cm})$ equilibrated with the same Tris/ $\mathrm{HCl}$ buffer until no absorbance at $280 \mathrm{~nm}$ was detected in the effluents, and then eluted with a linear gradient of $0-0.4 \mathrm{M}-\mathrm{NaCl}$ in $6000 \mathrm{ml} 20 \mathrm{mM}-\mathrm{Tris} / \mathrm{HCl}$ buffer, $\mathrm{pH} 7.5$. This procedure was done three times. Active glucosyltransferase fractions were pooled for each peak and dialysed against $\mathrm{Tris} / \mathrm{HCl}$ buffer, $\mathrm{pH}$ 7.5. The peaks were designated $\mathrm{P}-1$ ( $\mathrm{pI} 5 \cdot 8$ ), $\mathrm{P}-2$ ( $\mathrm{pI} 5 \cdot 5), \mathrm{P}-3(\mathrm{pl} \mathrm{5} \cdot 1)$ and $\mathrm{P}-4$ ( $\mathrm{pI} 4 \cdot 2)$ according to their order of elution from the column (Takehara $e t$ al., 1984). Each enzyme fraction was concentrated by ultrafiltration with Amicon PM 10 and used for further studies. P-1 solution ( $2 \mathrm{ml}$ ) was applied to an FPLC (Mono Q) column equilibrated with Tris/HCl buffer and washed with the same buffer. The column was then eluted with a linear gradient of $0-0 \cdot 2 \mathrm{M}-\mathrm{NaCl}$ in $30 \mathrm{ml} 20 \mathrm{~mm}$-Tris/ $\mathrm{HCl}$ buffer, $\mathrm{pH} 7.5$. This procedure was done seventeen times. The enzyme activity contained in pooled fractions was concentrated using Immersible CX-30 (Millipore) and dialysed against $50 \mathrm{~mm}$-sodium acetate buffer, $\mathrm{pH}$ 6.0.

Ammonium sulphate was added to the enzyme solution $(2.4 \mathrm{ml})$ to $25 \%$ saturation. Then the enzyme was applied to a column of Octyl-Sepharose CL-4B $(1.6 \times 15 \mathrm{~cm})$ equilibrated with the same buffer containing ammonium sulphate at $25 \%$ saturation. The enzyme was eluted with a linear gradient of ammonium sulphate at $25-0 \%$ saturation and $0-60 \%(v / v)$ ethylene glycol in the same buffer. This procedure was repeated twice. The active enzyme fractions were then pooled and concentrated using an Amicon PM 10 membrane and dialysed against $50 \mathrm{mM}$-sodium acetate buffer, $\mathrm{pH} 6 \cdot 0$.

PAGE. PAGE of the purified enzyme was done according to the method of Davis (1964). The sample (about $6 \mu \mathrm{g}$ protein) was applied to a separation gel of $7.5 \%(\mathrm{w} / \mathrm{v})$ acrylamide in $5 \mathrm{~mm}$-Tris/glycine buffer $(\mathrm{pH} 8.4)$. After electrophoresis, the gel was stained with Coomassie brilliant blue R-250. For detection of enzyme activity, the gel was incubated for $18 \mathrm{~h}$ at $37^{\circ} \mathrm{C}$ in $0.1 \mathrm{M}$-sodium acetate buffer, $\mathrm{pH} 5 \cdot 2$, containing $5 \mathrm{~mm}$-sodium fluoride and $5 \%$ $(w / v)$ sucrose. Carbohydrate was stained with the periodic acid-Schiff (PAS) reagent (Kapitany \& Zebrowski, 1973).

SDS-PAGE. This was done according to the method of Weber \& Osborn (1969) in order to determine the homogeneity and $M_{\mathrm{r}}$ of the purified enzyme. The run was made at $\mathrm{pH} 7.2$ in a $7 \%(\mathrm{w} / \mathrm{v})$ polyacrylamide gel containing $0.1 \%(w / v)$ SDS. The gel was stained for protein with Coomassie brilliant blue R-250.

$I E F$. IEF in a thin polyacrylamide gel layer was done as described by Mukasa $e t$ al. (1982), with some modifications. Polyacrylamide containing $4.4 \%(\mathrm{w} / \mathrm{v})$ acrylamide, $0 \cdot 14 \%(\mathrm{w} / \mathrm{v})$ methylenebisacrylamide, $3.3 \%$ (v/v) Pharmalyte $(\mathrm{pH} \mathrm{3-10)}$ and 3.0\% (v/v) Pharmalyte $(\mathrm{pH} \mathrm{4-6.5)}$ was covalently bound to a siliconized glass plate. The cathode and anode of the polyethylene glycol strips were soaked in $1 \mathrm{M}-\mathrm{NaOH}$ and $0.04 \mathrm{M}$-aspartic acid, respectively. A prefocusing run was done at $18^{\circ} \mathrm{C}$ at $100 \mathrm{~V}$ for $1.5 \mathrm{~h}$. After the prefocusing, enzyme solution was put on the gel surface and IEF subsequently done at $300 \mathrm{~V}$ for $3 \mathrm{~h}$. After the focusing, the $\mathrm{pH}$ of the gel was measured directly with a surface pH electrode (SE1600GC, Fuji Kagaku Keisoku, Tokyo, Japan) and protein was also stained with Coomassie brilliant blue R-250.

Ultracentrifugal analysis. The purified enzyme fraction was loaded onto linear $10-30 \%(\mathrm{v} / \mathrm{v})$ glycerol gradients, which were then centrifuged and fractionated as described by Newman et al. (1980). Alcohol dehydrogenase and catalase were used as $M_{\mathrm{r}}$ markers in the same gradients. 
Protein assay. Protein concentration was measured by the method of Bradford (1976) with bovine serum albumin as a standard.

Glucan assay. Glucan produced by the purified enzyme was separated by $70 \%(\mathrm{v} / \mathrm{v})$ ethanol precipitation as reported by Koga \& Inoue (1978). Periodate oxidation and Smith degradation were done by the method of Hamilton \& Smith (1956). Degraded products were analysed by HPLC (SCR 101N column, Shimadzu, Kyoto, Japan).

Antiserum against the purified enzyme. Purified P-1 ( $90 \mu \mathrm{g}$ protein) was mixed with an equal volume of Freund's incomplete adjuvant and injected intradermally into a rabbit. The animal received three injections of antigen at intervals of one week and antiserum was collected from an ear vein $10 \mathrm{~d}$ after the final injection.

Immunodiffiusion. Ouchteriony double-immunodiffusion analysis (Ouchterlony, 1958) was done in $1 \%$ (w/v) agarose gel.

Purification of the P-3 and P-4 enzymes. We purified both P-3 and P-4 in order to confirm whether the three glucosyltransferases separated by DEAE-cellulose chromatography were indeed immunologically different from each other.

The third peak eluted from the DEAE-cellulose column, which was the total glucosyltransferase activity fraction containing P-3, was rechromatographed on DEAE-cellulose and eluted with a linear gradient of $0-0 \cdot 3 \mathrm{M}$ $\mathrm{NaCl}$ in $20 \mathrm{~mm}$-Tris/ $\mathrm{HCl}$ buffer, $\mathrm{pH} \mathrm{7.5}$, in a total volume of $1000 \mathrm{ml}$. Water-insoluble glucan synthetic activity fractions were pooled and concentrated with Amicon PM 10. P-3 was again chromatographed on a Bio-Gel A-5m column and its pooled fractions were concentrated with Amicon PM 10. Further purification was done by using hydrophobic chromatography with Octyl-Sepharose CL-4B and FPLC (Mono Q column) in a similar manner to that used for the P-1 preparation. The last step of the purification procedures was done by using HPLC employing a TSK-gel G3000SW column (ToyoSoda, Tokyo, Japan) with $50 \mathrm{mm-sodium} \mathrm{acetate} \mathrm{buffer,} \mathrm{pH} \mathrm{6.0,} \mathrm{containing}$ $0.1 \mathrm{M}-\mathrm{NaCl}$ and $0.02 \%(\mathrm{w} / \mathrm{v}) \mathrm{NaN}_{3}$. Water-insoluble glucan synthetic activities were pooled and concentrated with Immersible CX-30 and dialysed against $50 \mathrm{~mm}$-sodium acetate buffer, pH 6.0. This dialysed enzyme preparation was subjected to the gel precipitation reaction.

Total glucosyltransferase activity in the fourth peak, which contained P-4, was chromatographed on an Ultrogel AcA 34 column. Active fractions were collected and condensed using Amicon PM 10 as above, and subjected to immunodiffusion analysis.

\section{RESULTS}

\section{Separation of the four glucosyltransferases}

A typical chromatogram of glucosyltransferases on DEAE-cellulose is shown in Fig. 1. The crude solution was prepared from about 33 litres of culture solution and its volume reduced to $540 \mathrm{ml}$ by ammonium sulphate precipitation. Glucosyltransferase activity was found in four peaks. Dextranase activity was observed neither in P-1 nor in P-2, but mostly in the P-4 fractions. From another run, four enzymes accounting for the total glucosyltransferase activity were also obtained from 100 litres of culture medium. The P-1, P-2 and P-4 fractions basically produced water-soluble glucan, whereas P-3 synthesized water-insoluble glucan.

\section{Purification of the P-1 enzyme}

After pooling and concentration of the first active peak obtained from the DEAE-cellulose column, it was subjected to FPLC (Mono Q column) (Fig. 2). The eluate was concentrated and loaded on an Octyl-Sepharose CL-4B column for hydrophobic chromatography (Fig. 3). The purification procedures are summarized in Table 1 . The specific activity of the final preparation was 244 times greater than that of the crude ammonium sulphate fraction; the yield was $1.2 \%$.

This purified P-1 synthesized water-soluble glucan. With a high concentration of this purified enzyme, clear water-soluble glucan was found as the sole product in the reaction mixture.

\section{Homogeneity of the P-1 enzyme}

Purified P-1 exhibited a homogeneous electrophoretic profile in PAGE (Fig. 4a) and in SDSPAGE (Fig. 5). It was confirmed that the protein band was, indeed, the glucosyltransferase by the positive glucan stain obtained with PAS after incubation of the gel in sucrose solution (Fig. $4 b)$. 


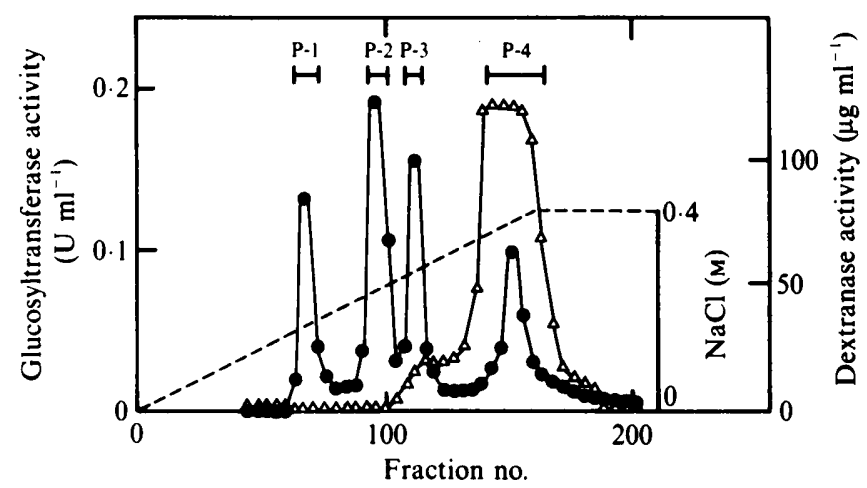

Fig. 1. Separation pattern of $S$. mutans AHT extracellular glucosyltransferases on DEAE-cellulose. Chromatography of the ammonium sulphate fraction of glucosyltransferases was carried out on a DEAE-cellulose column $(9 \times 36 \mathrm{~cm})$ as described in Methods. The flow rate was $246 \mathrm{ml} \mathrm{h}^{-1}$ and $30 \mathrm{ml}$ fractions were collected. - Total glucosyltransferase activity; $\triangle$, dextranase activity (expressed as the amount of reducing sugar equivalent to $\mu \mathrm{g}$ glucose $\left.\mathrm{ml}^{-1}\right) ;----, \mathrm{NaCl}$ concentration. Fractions indicated by the horizontal lines were pooled.

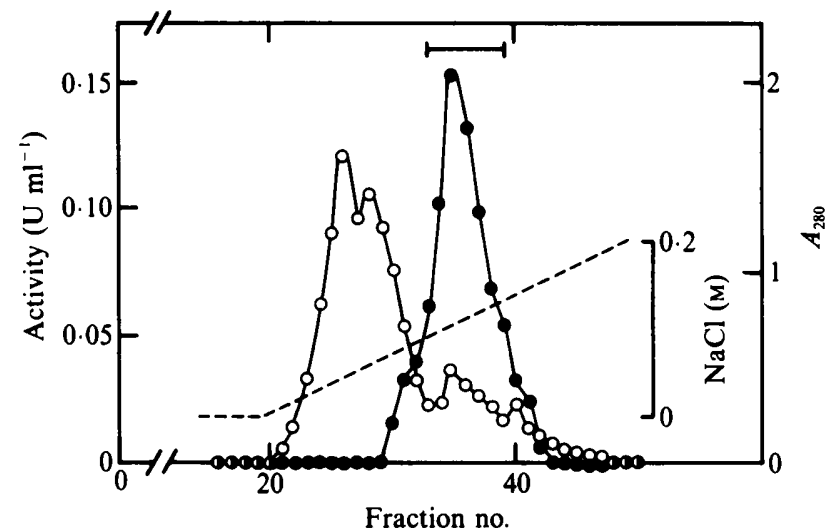

Fig. 2. Elution profile of P-1 enzyme (P-1 fraction obtained from the DEAE-cellulose column, pI 5-8) on an FPLC (Mono Q) column. Experimental details are given in Methods. The flow rate was $1 \mathrm{ml} \mathrm{min}^{-1}$ and fractions of $1 \mathrm{ml}$ were collected. 0 . Total glucosyltransferase activity; $O$, protein monitored by the absorbance at $280 \mathrm{~nm} ;----, \mathrm{NaCl}$ concentration. Fractions indicated by the horizontal line were pooled.

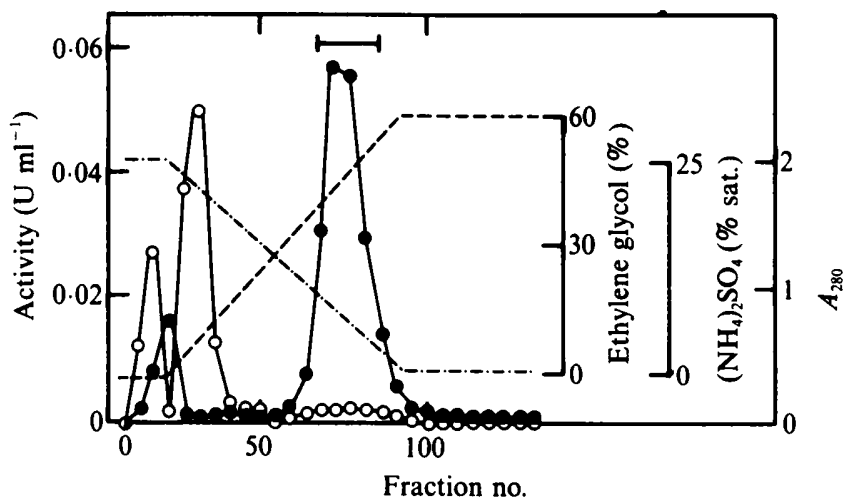

Fig. 3. Elution profile of P-1 enzyme (pI 5.8) on an Octyl-Sepharose CL-4B column $(1.6 \times 15 \mathrm{~cm})$. Experimental details are given in Methods. The flow rate was $25 \mathrm{ml} \mathrm{h}^{-1}$ and $5 \mathrm{ml}$ fractions were collected. - Total glucosyltransferase activity; $O$, protein monitored by the absorbance at $280 \mathrm{~nm}$; $-\cdot-\cdot$, ammonium sulphate concentration; -----, ethylene glycol concentration. 


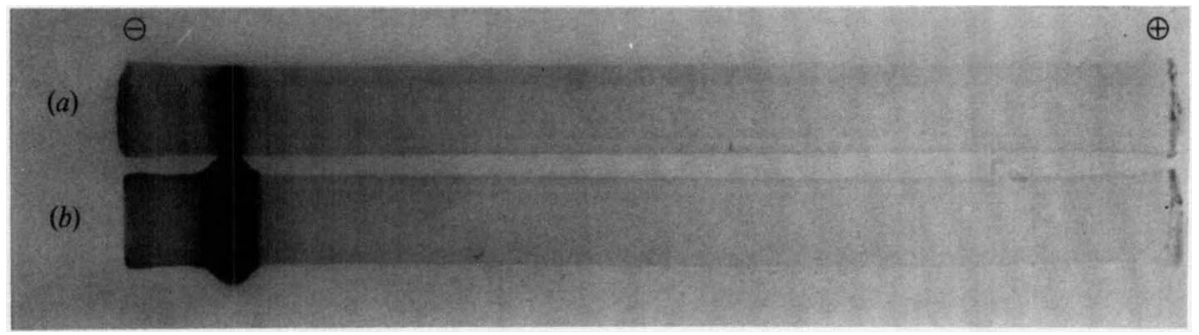

Fig. 4. PAGE (7.5\%, w/v, polyacrylamide) analysis of the purified P-1 enzyme (pI 5.8) (6 $\mu \mathrm{g}$ protein). (a) Protein staining with Coomassie brilliant blue R-250; (b) activity staining with PAS reagent (see Methods).

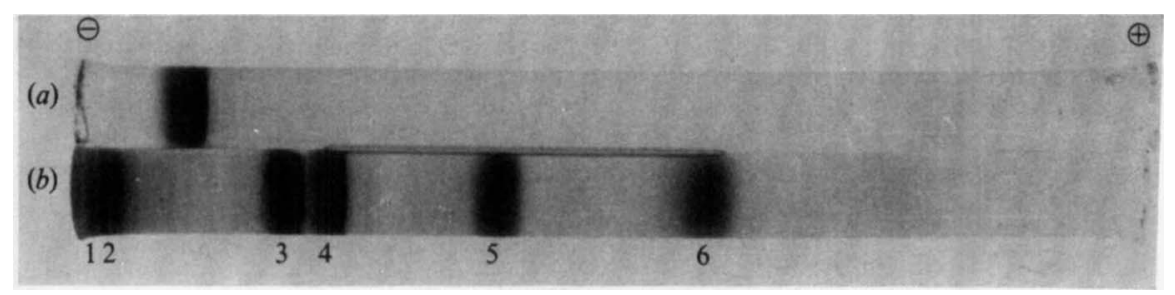

Fig. 5. SDS-PAGE $(7 \%, w / v$, polyacrylamide) analysis of the purified P-1 enzyme (pI 5.8) $(6 \mu \mathrm{g}$ protein). The enzyme was heated at $100{ }^{\circ} \mathrm{C}$ for $3 \mathrm{~min}$ in a solution which contained $10 \mathrm{~mm}$-sodium phosphate buffer, pH 7.2, in the presence of $1 \%(w / v)$ SDS and $5 \%(v / v) 2$-mercaptoethanol. (a) Purified P-1; (b) protein standards (1, thyroglobulin, $M_{\tau} 330000 ; 2$, ferritin half unit, $220000 ; 3$, bovine serum albumin, $67000 ; 4$, catalase, $60000 ; 5$, lactate dehydrogenase, $36000 ; 6$, ferritin, 18500).

Table 1. Purification of the P-1 enzyme from $S$. mutans $A H T$

\begin{tabular}{|c|c|c|c|c|c|c|}
\hline Step & $\begin{array}{l}\text { Volume } \\
\text { (ml) }\end{array}$ & $\begin{array}{l}\text { Total } \\
\text { activity } \\
\text { (U) }\end{array}$ & $\begin{array}{c}\text { Total } \\
\text { protein } \\
(\mathrm{mg})\end{array}$ & $\begin{array}{l}\text { Specific } \\
\text { activity } \\
\left(\mathrm{U} \mathrm{mg}^{-1}\right)\end{array}$ & $\begin{array}{c}\text { Purifica- } \\
\text { tion } \\
(- \text { fold })\end{array}$ & $\begin{array}{c}\text { Yield } \\
(\%)\end{array}$ \\
\hline $\begin{array}{l}\text { Ammonium sulphate } \\
\text { DEAE-cellulose } \\
\text { FPLC (Mono Q) } \\
\text { Octyl-Sepharose CL-4B }\end{array}$ & $\begin{array}{c}1620 \\
34 \\
4 \cdot 8 \\
5\end{array}$ & $\begin{array}{c}562 \\
29 \\
8.8 \\
6 \cdot 8\end{array}$ & $\begin{array}{r}6026 \\
8 \cdot 16 \\
1 \cdot 39 \\
0 \cdot 30\end{array}$ & $\begin{array}{l}0.093 \\
3.55 \\
6.33 \\
22 \cdot 67\end{array}$ & $\begin{array}{r}1 \\
38 \\
68 \\
244\end{array}$ & $\begin{array}{r}100 \\
5 \cdot 2 \\
1 \cdot 6 \\
1 \cdot 2\end{array}$ \\
\hline
\end{tabular}

\section{Physical and kinetic properties of the P-I enzyme}

P-1 did not form multiple protein bands in IEF and had a single pI of 5.8 (Fig. 6). Estimations of the $M_{\mathrm{r}}$ of this enzyme by two methods, SDS-PAGE and ultracentrifugation, yielded figures of about 130000 and about 135000 respectively. The reaction of the enzyme was linear with time up to $60 \mathrm{~min}$ at an optimal $\mathrm{pH}$ of $4 \cdot 7$, (determined in a $\mathrm{pH}$ range using $0.2 \mathrm{M}$-sodium acetate and $0.2 \mathrm{M}$-Tris/HCl buffer), and the optimal temperature was about $37^{\circ} \mathrm{C}$. The $K_{\mathrm{m}}$ for sucrose was $3.9 \pm 0.2 \mathrm{mM}$ (mean $\pm \mathrm{SD})$ under the reaction conditions mentioned above.

The enzyme activity was not stimulated by DT 10 . Glucoside linkages of glucan from sucrose catalysed by this enzyme were examined by periodate oxidation and Smith degradation, and two linkages, $1,6-\alpha-D$ and $1,3-\alpha-D$, with molar ratios of $91.5 \%$ and $8.6 \%$, respectively, were found. No $1,4-\alpha-D$ linkage was apparent.

\section{Immunological properties of the P-I enzyme}

In order to have controls for the immunodiffusion analysis, P-3 was highly purified and P-4 was partially purified. The results of the gel precipitation studies with $\mathrm{P}-1, \mathrm{P}-3$ and $\mathrm{P}-4$ against 


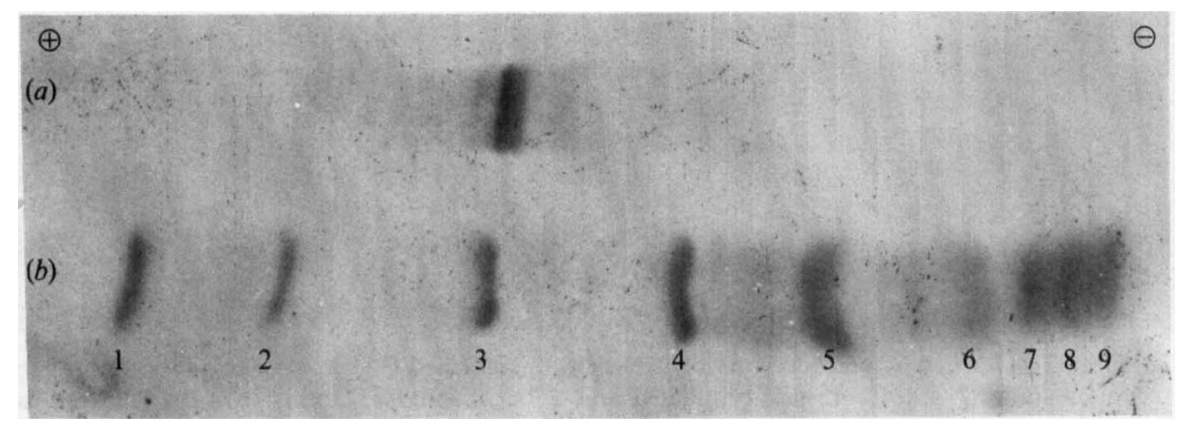

Fig. 6. IEF analysis of the purified P-1 enzyme (pI 5.8). (a) Purified P-1; (b) protein standards (1, soybean trypsin inhibitor, pI $4 \cdot 55 ; 2, \beta$-lactoglobulin $A, 5 \cdot 20 ; 3$, bovine carbonic anhydrase $B, 5 \cdot 85 ; 4$, human carbonic anhydrase $B, 6.55 ; 5$, horse myoglobin - acidic band, $6.85 ; 6$, horse myoglobin - basic band, $7 \cdot 35 ; 7$, lentil lectin - acidic band, $8 \cdot 15 ; 8$, lentil lectin - middle band, $8 \cdot 45 ; 9$, lentil lectin - basic band, $8 \cdot 65$ ).

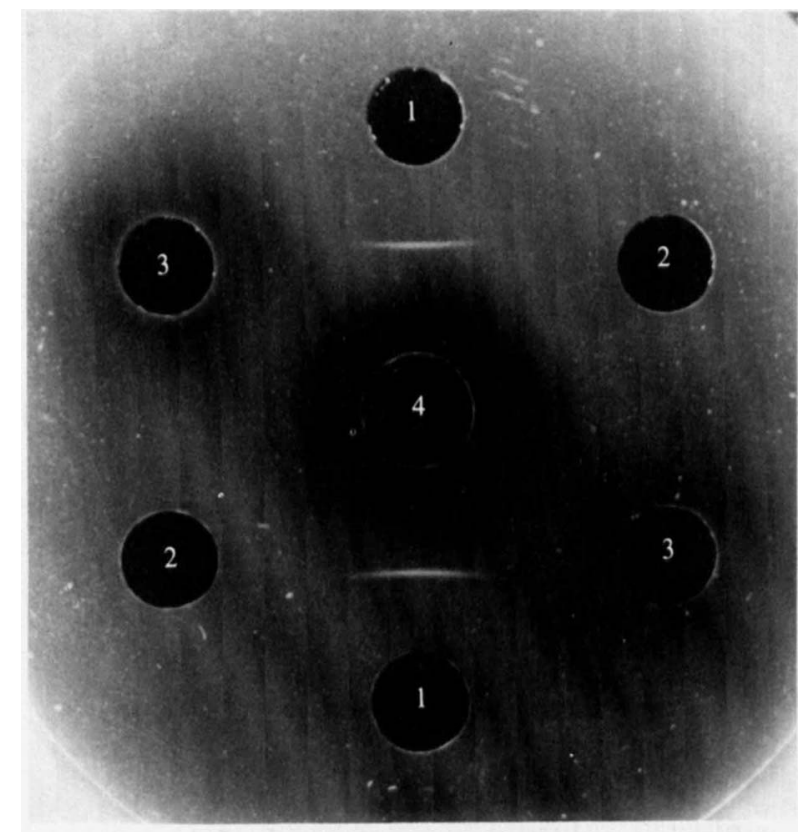

Fig. 7. Double immunodiffusion of glucosyltransferases from $S$. mutans AHT against anti-P-1 serum. 1, Purified P-1 (pI 5.8, 1.2 $\mu$ g protein); 2, purified P-3 (pI 5.5, $1.8 \mu \mathrm{g}$ protein); 3, partially purified P-4 (pI 4.2, 14.9 $\mu \mathrm{g}$ protein); 4 , anti-P-1 serum.

rabbit anti-P-1 serum are shown in Fig. 7. After $12 \mathrm{~h}$ incubation, the anti-P-1 serum formed a single precipitin band against the purified $\mathrm{P}-1$ but not against the other two enzymes. Serum from a rabbit which had not been injected with P-1 did not show any precipitation with the P-1.

\section{DISCUSSION}

The manifestation of cariogenicity in $S$. mutans depends on the nature of the glucan that is synthesized from sucrose by the extracellular glucosyltransferases produced by this organism. It is essential for $S$. mutans to possess mechanisms for synthesizing water-insoluble glucan with adhesive properties in order for the organism to adhere to the tooth surface. Certain 
glucosyltransferases are responsible for synthesizing water-insoluble glucan. Without the cooperative action of these enzymes, it would not be possible for this organism to have any degree of adhesion. Each of the enzymes alone lacks the ability to produce adherence to the glass of a test tube (Fukushima et al., 1981; Inoue et al., 1982). Thus, their cooperative effect is a particular characteristic of $S$. mutans. For this reason, the function of each individual enzyme should be considered, rather than lumping them together as a single glucosyltransferase entity, when discussing the mechanism of caries formation.

We have previously isolated four enzymes from crude glucosyltransferase by DEAE-cellulose chromatography, and have determined their isoelectric points (Takehara et al., 1984), immunological properties and some characteristics of the glucans they produce.

According to our findings, P-1, P-3 and P-4 are different proteins (see Fig. 7). P-1 did not form multiple protein bands in IEF (Fig. 6). The enzyme had a very strong auto-priming effect compared with P-4 (Takehara et al., 1984). When either P-3 or P-4 was incubated with P-3 maintained at a constant level, the auto-priming ability of P-1 was 3.5 times as strong as that of P-4 (Takehara et al., 1984). This suggests that P-1 is essential for glucan synthesis of $S$. mutans serotype $g$.

The low yield of P-1 (1.2\%) leads to the question of whether this activity accounts for a significant proportion of the glucosyltransferase activity in vivo. However, the overall yield of primer-dependent glucosyltransferase (pI 4.1) activity obtained by Shimamura et al. (1982) was also low $(3.8 \%$ ), despite the addition of DT 10 . This glucosyltransferase (pI $4 \cdot 1)$ probably corresponds to $\mathrm{P}-4$. The in vivo significance of $\mathrm{P}-1$ relative to other enzymes is not known at present.

The existence of this enzyme, with a pI of $5 \cdot 8$, does not appear to be widely known. The review article by Ciardi (1983), and a recent paper of Furuta et al. (1985), made no mention of this enzyme. We therefore consider the purification procedures, and various physical, enzymic and immunological properties presented here of this newly discovered glucosyltransferase from $S$. mutans serotype $g$ to be significant.

This work was taken from a dissertation submitted by Nobuhiro Hanada to the Graduate School of Kyushu Dental College in partial fulfilment of the requirements for the PhD degree.

\section{REFERENCES}

BRADFORD, M. M. (1976). A rapid and sensitive method for the quantitation of microgram quantities of protein utilizing the principle of protein-dye binding. Analytical Biochemistry 72, 248-254.

Clardi, J. E. (1983). Purification and properties of glucosyltransferase from Streptococcus mutans: a review. In Glucosyltransferases, Glucans, Sucrose and Dental Caries, pp. 51-64. Edited by R. J. Doyle \& J. E. Ciardi. Washington, DC: IRL Press.

Ciardi, J. E., Beaman, A. J. \& Wittenberger, C. L. (1977). Purification, resolution, and interaction of the glucosyltransferases of Streptococcus mutans 6715. Infection and Immunity 18, 237-246.

DAvis, B. J. (1964). Disc electrophoresis. II. Method and application to human serum proteins. Annals of the New York Academy of Sciences 121, 404-427.

Fukushima, K., Motoda, R., Takada, K.\& IKeda, T. (1981). Resolution of Streptococcus mutans glucosyltransferases into two components essential to waterinsoluble glucan synthesis. FEBS Letters 128, 213216.

Furuta, T., Koga, T., Nishizawa, T., OKahashi, N. \& HamadA, S. (1985). Purification and characterization of glucosyltransferases from Streptococcus mutans 6715. Journal of General Microbiology 131, 285293.
Halhoul, M. N. \& Kleinberg, I. (1972). Differential determination of glucose and fructose, and glucoseand fructose-yielding substances, with anthrone. Analytical Biochemistry 50, 337-343.

Hamada, S. \& TORII, M. (1978). Effect of sucrose in culture media on the location of glucosyltransferase of Streptococcus mutans and cell adherence to glass surfaces. Infection and Immunity 20, 592-599.

Hamada, S., Masuda, N. \& Kotani, S. (1978). Demonstration of serotype $d$ and $g$ specificities of Streptococcus mutans by immunodiffusion. Archives of Oral Biology 23, 495-499.

Hamilton, J. K. \& SMITH, F. (1956). Reduction of periodate oxidation of carbohydrate. II. A new method for the end-group assay of amylopectin. Journal of the American Chemical Society 78, 59075909.

Inoue, M., Koga, T., Sato, S. \& Hamada, S. (1982). Synthesis of adherent insoluble glucan by the concerted action of the two glucosyltransferase components of Streptococcus mutans. FEBS Letters 143, 101-104.

Kapitany, R. A. \& Zebrowski, E. J. (1973). A high resolution PAS stain for polyacrylamide gel electrophoresis. Analytical Biochemistry 56, 361-369.

KOGA, T. \& INOUE, M. (1978). Cellular adherence, 
glucosyltransferase adsorption, and glucan synthesis of Streptococcus mutans AHT mutants. Infection and Immunity 19, 402-410.

Koga, T., Sato, S., YakushiJi, T. \& Inoue, M. (1983). Separation of insoluble and soluble glucan-synthesizing glucosyltransferases of Streptococcus mutans OMZ 176 (serotype d). FEMS Microbiology Letters 16, 127-130.

Mukasa, H., Shimamura, A. \& Tsumori, H. (1982). Direct activity stains for glycosidase and glucosyltransferase after isoelectric focusing in horizontal polyacrylamide gel layers. Analytical Biochemistry 123, 276-284.

Newman, B. M., White, P., Mohan, S. B. \& Cole, J. A. (1980). Effect of dextran and ammonium sulphate on the reaction catalysed by a glucosyltransferase complex from Streptococcus mutans. Journal of General Microbiology 118, 353-366.

OUCHTERLONY, O. (1958). Diffusion in gel methods for immunological analysis. Progress in Allergy 5, 1-9.

Park, J. T. \& Johnson, M. J. (1949). A submicro determination of glucose. Journal of Biological Chemistry 181, 149-151.
Robyt, J. F. \& Martin, P. J. (1983). Mechanism of synthesis of D-glucans by D-glucosyltransferases from Streptococcus mutans 6715. Carbohydrate Research 113, 301-315.

Shimamura, A., Tsumori, H. \& MUkasa, H. (1982). Purification and properties of Streptococcus mutans extracellular glucosyltransferase. Biochimica et biophysica acta 702, 72-80.

Shimamura, A., Tsumori, H. \& MUKasa, H. (1983). Three kinds of extracellular glucosyltransferases from Streptococcus mutans 6715 (serotype g). FEBS Letters 157, 79-84.

Takehara, T., Hanada, N. \& SaEki, E. (1984). Interaction of glucosyltransferase isozymes on glucan synthesis by Streptococcus mutans AHT (serotype g). Microbios Letters 27, 113-120.

WEBER, K. \& OSBORN, M. (1969). The reliability of molecular weight determinations by dodecyl sulfatepolyacrylamide gel electrophoresis. Journal of Biological Chemistry 244, 4406-4412. 